\title{
Characterization of Micrococcus antarcticus sp. nov., a psychrophilic bacterium from Antarctica
}

\author{
Hongcan Liu, Yi Xu, Yanhe Ma and Peijin Zhou
}

Institute of Microbiology, Chinese Academy of Sciences, Beijing, 100080 China
Author for correspondence: Peijin Zhou. Tel: +86 10625 53628. Fax: +861062560912. e-mail: zhou@sun.im.ac.cn

Keywords: cold-adapted bacteria, Micrococcus antarcticus, phylogeny

\section{INTRODUCTION}

Cold-adapted micro-organisms are more likely to be found in permanently cold environments such as polar regions, marine environments and other areas. They take on a process of nutrient cycling and primary biomass production (Bowman et al., 1997). The ability to grow at low temperatures seems to have been acquired over evolutionary time by all the major groupings of micro-organisms, and the range of species within a particular cold habitat reflects those many different parameters (e.g. primary nutrient, $\mathrm{pH}$, salinity) to which an organism must adapt if it is to compete successfully with others (Gounot, 1991). Morita proposed that cold-adapted micro-organisms were divided into two groups, i.e. obligately psychrophilic micro-organisms (psychrophiles) and facultatively psychrophilic micro-organisms (psychrotrophs), The psychrophiles, besides having the ability to grow at or below $0{ }^{\circ} \mathrm{C}$, have an optimum growth temperature below $15^{\circ} \mathrm{C}$ and a maximum growth temperature below $20^{\circ} \mathrm{C}$; the psychrotrophs have a minimum growth temperature at or above $0{ }^{\circ} \mathrm{C}$ and optimum and maximum growth temperatures above $20^{\circ} \mathrm{C}$ (Russell, 1998). To date, the predominant

The GenBank/EMBL/DDBJ accession number for the $16 \mathrm{~S}$ rRNA sequence of strain $\mathrm{T2}^{\top}$ is AJ005932. psychrophilic bacteria in Antarctica were found to belong to four phylogenetic groups, i.e. the $\alpha$ and $\gamma$ subclasses of the Proteobacteria, the Gram-positive branch and the Flexibacter-Bacteroides-Cytophaga phylum (Nichols et al., 1995). During an investigation into the bacterial diversity of Antarctic region, Grampositive coccoid cells were frequently observed and isolated. In this study, the characterization of isolate $\mathrm{T} 2^{\mathrm{T}}$ was detailed and the results showed that strain $\mathrm{T} 2^{\mathrm{T}}$ represented a new species within the genus Micrococcus, for which the name Micrococcus antarcticus is proposed.

\section{METHODS}

Bacterial strains and cultural conditions. Strain $\mathrm{T}^{\mathrm{T}}$ was enriched by shaking in peptone/yeast extract/glucose (PYG) medium at $0-5{ }^{\circ} \mathrm{C}$ and then identified on PYG medium consisting of the following $\left(\mathrm{g}^{-1}\right)$ : peptone (5), yeast extract (10) and glucose (5) g, adjusted to $\mathrm{pH} 7 \cdot 0$ and then incubated at $10^{\circ} \mathrm{C}$. The growth temperature range was determined using a temperature-gradient incubator (TN3F; Advantec). Micrococcus luteus (IFO 3333) and Micrococcus lylae (IFO 15355) were provided by the Institute for Fermentation, Osaka (IFO), Japan.

Morphological studies. Cell morphology was observed under a light microscope and under a scanning electron microscope by using cells in the exponential growth phase grown on PYG medium. 
Biochemical characterization. The biochemical and physiological characteristics of the isolate were investigated using the methods described by Barrow \& Feltham (1993) and some physiological properties were tested using the BIOLOG GP-plate, System Release 3.50. Comparative investigations of biochemical and physiological characteristics and molecular features were carried out with $M$. luteus and M. lylae.

Chemotaxonomic characterization. Amino acid analysis of the cell wall was performed as follows. Cell wall was prepared from $500 \mathrm{mg}$ dried cells by mechanical disruption with an ultrasonic oscillator and was purified as described by Schleifer \& Kandler (1972). The amino acid composition of cell wall hydrolysates was determined by using an automatic amino acid analyser (model L-8500A; Hitachi) HPLC apparatus equipped with an ion-exchange column (model 2620MSC). For sugar analysis, cell wall was hydrolysed with $2 \mathrm{M} \mathrm{HCl}$ at $100^{\circ} \mathrm{C}$ for $2 \mathrm{~h}$, dried in a vacuum and then analysed by TLC on cellulose plates. Fatty acids were extracted from dry cells by methanolysis and were examined by using a gas chromatography apparatus (model GC-8A; Shimadzu).

Menaquinone profiles were examined using HPLC (Stackebrandt et al., 1995) with apparatus (model 510; Waters) equipped with an II5C18 HG column (Wakoshi).

DNA base composition and DNA-DNA hybridization. Cells were grown in $\mathrm{PYG}$ at $10^{\circ} \mathrm{C}$ on a rotary shaker. After incubation for $72 \mathrm{~h}$, cells were harvested and washed with distilled water. DNA was isolated and purified by the method of Sambrook et al. (1989). The G+C content of the DNA was determined by the method of thermal denaturation (Sly et al., 1986) with a UV-1206 UV-Vis spectrophotometer (Shimadzu). DNA-DNA hybridization was carried out as described by Tindall et al. (1984), with a minor modification. DNA fragments were labelled with $\left[\alpha^{-32} \mathrm{P}\right] \mathrm{dCTP}$ according to the instructions provided with the Boehringer Mannheim nick translation kit.

16S rDNA sequence determination and phylogenetic analysis. The $16 \mathrm{~S}$ rRNA gene was amplified by the PCR with primers 43F (5'-TCAGAACGAACGCTGGCGGC-3') and 1541R (5'-AAGGAGGTGATCCAGCC-3') using strain $\mathrm{T} 2^{\mathrm{T}}$ total DNA as the DNA template. Purified PCR products were cloned according to the manufacturer's instructions (Promega). The sequencing reactions were carried out using the ABI PRISM Dye primer cycle sequencing ready reaction kit (Applied Biosystems). Sequencing was performed on an ABI 373S DNA sequencer (Applied Biosystems) and the sequence was submitted to the EMBL nucleotide sequence database. The reference $16 \mathrm{~S}$ rRNA gene sequence data used in this study were obtained from the GenBank nucleotide database.

The 16S rRNA gene sequence determined in this work was aligned with previously published sequences by using the multiple-sequence alignment program CLUSTAL W version 1.74 (Thompson et al., 1994). Evolutionary distances were calculated with the Kimura two-parameter calculation model. Alignment positions with insertion or deletion were excluded for the calculations. The phylogenetic tree was constructed using the neighbour-joining method with the Kimura two-parameter calculation model in TREECON for Windows version 1.2 (Van de Peer \& De Wachter, 1994). As references, other phylogenetic trees were also constructed with other techniques in PHYLIP version 3.572, such as the parsimony and maximum-likelihood methods (Felsenstein, 1993).
Nucleotide sequence accession numbers. The 16S rRNA gene sequences of the test strains have the following GenBank/EMBL/DDBJ accession numbers (in parentheses): Arthrobacter protophormiae (X80745); Arthrobacter nicotianae (X80739); Arthrobacter sulfureus (X83409); Arthrobacter ramosus (X80742); Arthrobacter globiformis (M23411); Arthrobacter atrocyaneus (X80746); Arthrobacter crystallopoietes (X80738); Arthrobacter citreus (X80737); Arthrobacter oxydans (X83408); Arthrobacter ilicis (X83407); Arthrobacter histidinolovorans (X83406); Kocuria varians (X87754); Kocuria kristinae (X80749); Kocuria erythromyxa (Y11330); Kocuria rosea (X87756); Microccus lylae (X80750); Microccus luteus (M38242); Rothia dentocariosa (M59055); Stomatococcus mucilaginosus (X87758). The tree was rooted by using the $16 \mathrm{~S}$ rDNA sequence of Kytococcus sedentarius (X87755) as an outgroup.

\section{RESULTS AND DISCUSSION}

\section{Cultural characteristics}

On PYG medium, the cells of strain $\mathrm{T} 2^{\mathrm{T}}$ were spherical $(0.5-0.8 \mu \mathrm{m})$, occurred in pairs and packets and were non-motile, Gram-positive and aerobic. Endospores were not detected. Colonies were yellow, mucoid and fluffy with entire margins. The catalase test was positive. The optimum temperature for growth was $16.8^{\circ} \mathrm{C}$ (Fig. 1) and growth occurred at $0^{\circ} \mathrm{C}$. The physiological and biochemical characteristics are summarized in Table 1. Differentiation of the new species from other Micrococcus species is achieved by means of some physiological properties (Table 1); for example, it differs from $M$. luteus and $M$. lylae by hydrolysis of Tween and starch. In some respects (e.g. indole formation, Voges-Proskauer reaction, nitrate reduction), the isolate can be biochemically distinguished from the known species.

\section{Chemotaxonomic and genotypic characteristics}

Chemotaxonomic investigations revealed that the amino acids of peptidoglycan in the cell wall were glutamic acid, alanine, lysine and glycine in the molar ratio of $1: 1 \cdot 88: 0 \cdot 93: 0 \cdot 97$. The amino sugar in the cell wall polysaccharide was mannosamine. The predominant menaquinones were MK-8 (63.7\%) and MK-

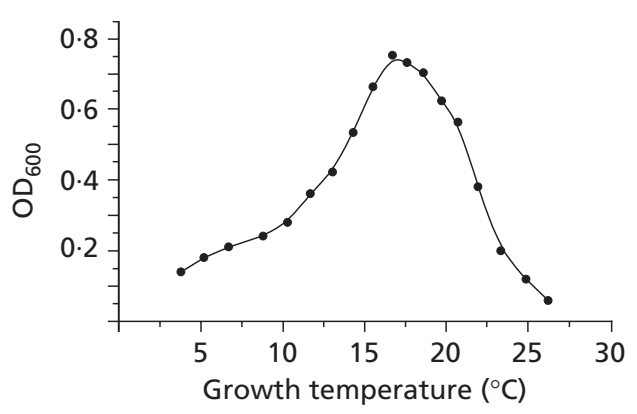

Fig. 1. Growth curve of Micrococcus antarcticus $T 2^{\top}$ at different temperatures. 
Table 1. Comparisons of phenotypical and physiological properties of members of genus Micrococcus

+ , Positive test result; - , negative test result. All three species shared test results for the following: morphology (coccoid); motility $(-)$; Gram stain $(+)$; catalase $(+)$; oxidase $(+)$; aesculin hydrolysis $(-)$; acid production from glucose $(-)$, fructose $(-)$, maltose $(-)$, sucrose $(-)$ and glycerol $(-)$; acetoin $(-)$; arginine dihydrolase $(-)$; lysozyme susceptibility $(+)$; antibiotic susceptibility to penicillin $(+)$, erythromycin $(+)$, streptomycin $(+)$, methicillin $(+)$, novobiocin $(+)$, tetracycline $(+)$, chloramphenicol $(+)$, neomycin $(+)$ and polymyxin $\mathrm{B}(+)$; and peptidoglycan type (lysine).

\begin{tabular}{|c|c|c|c|}
\hline Characteristic & M. luteus & M. lylae & $\begin{array}{c}\text { M. antarcticus } \\
\mathrm{T}^{\mathrm{T}}\end{array}$ \\
\hline $\begin{array}{l}\text { Optimal growth temp. } \\
\left({ }^{\circ} \mathrm{C}\right)\end{array}$ & 37 & 37 & $16 \cdot 8$ \\
\hline \multicolumn{4}{|l|}{ Hydrolysis of Tweens: } \\
\hline 20 & - & - & + \\
\hline 40 & - & - & + \\
\hline 80 & - & - & + \\
\hline Starch hydrolysis & - & - & + \\
\hline Urease & + & + & - \\
\hline Indole formation & - & - & + \\
\hline Nitrate reduction & - & - & + \\
\hline $\begin{array}{l}\text { Voges-Proskauer } \\
\text { reaction }\end{array}$ & - & - & + \\
\hline Methyl red test & + & - & + \\
\hline Quinone system & MK- 8, MK- $8\left(\mathrm{H}_{2}\right)$ & $\mathrm{MK}-8\left(\mathrm{H}_{2}\right)$ & MK-8, MK-8( $\left.\mathrm{H}_{2}\right)$ \\
\hline Cellular fatty acids* & $\mathrm{S}, \mathrm{A}, \mathrm{I}$ & $\mathrm{A}, \mathrm{I}$ & $\begin{array}{l}\text { anteiso- } \mathrm{C}_{15: 0} \\
\text { iso- } \mathrm{C}_{15: 0}\end{array}$ \\
\hline Cell wall amino sugar & Mannosamine & Galactosamine & Mannosamine \\
\hline $\mathrm{G}+\mathrm{C}$ content $(\mathrm{mol} \%)$ & $70 \cdot 0$ & 69 & $66 \cdot 4$ \\
\hline
\end{tabular}

*S, Straight-chain saturated; A, anteiso-methyl-branched; I, iso-methyl-branched.

$8\left(\mathrm{H}_{2}\right)(7 \cdot 4 \%)$. Major amounts of anteiso-methylbranched acid (anteiso- $\mathrm{C}_{15: 0} 49 \cdot 7 \%$ ), smaller amounts of iso-methyl-branched acid (iso- $\mathrm{C}_{15: 0} 19.9 \%$ ) and 12 methyl tetradecenoic acid (anteiso- $\mathrm{C}_{15: 1} 12 \cdot 3 \%$ ) were present. The $\mathrm{G}+\mathrm{C}$ content of the DNA was $66.4 \mathrm{~mol} \%$. These data were compatible with the assignment of the strain to the genus Micrococcus, thereby confirming the identity of the isolate $\mathrm{T} 2^{\mathrm{T}}$ as a member of the genus Micrococcus.

\section{Phylogenetic analysis}

To determine the phylogenetic position of isolate $\mathrm{T} 2^{\mathrm{T}}$, the 1497-base 16S rDNA sequence was determined and a phylogenetic tree based on $K_{\text {nuc }}$ values was created by comparison of the new sequence with other known relevant sequences in the GenBank database. The tree (Fig. 2) clearly indicated that strain $\mathrm{T}^{\mathrm{T}}$ and the other two known species of genus Micrococcus should be grouped into the same lineage. The apparent closest relative to strain $\mathrm{T}^{\mathrm{T}}$ was $M$. luteus, with a sequence similarity of $94.4 \%$; this branch received $100 \%$ bootstrap support. It is evident from both sequence divergence values and tree analysis that the isolate does not belong to to any other described species, and that the 16S rRNA sequence divergence $(>3 \%)$ unequivocally demonstrates that isolate $\mathrm{T} 2^{\mathrm{T}}$ represents a new Micrococcus species (Collins et al., 1999).

\section{DNA-DNA hybridization}

To verify the phylogenetically distinct position of strain $\mathrm{T}^{\mathrm{T}}$ as determined by $16 \mathrm{~S}$ rDNA sequence analysis, the degree of DNA-DNA similarity was determined for strain $\mathrm{T}^{\mathrm{T}}$ and two Micrococcus species. The DNA-DNA similarity between strain T2 $2^{\mathrm{T}}$ and $M$. luteus and $M$. lylae was 34.4 and $28.8 \%$, respectively. DNA similarities were clearly below $70 \%$ (which is considered to be the threshold value for the delineation of genospecies).

The genus Micrococcus was first introduced by Cohn (Kocur et al., 1991) and since then the description has been revised several times. Stackebrandt et al. (1995) proposed an emended description of the genus Micrococcus. To date, $M$. luteus and $M$. lylae are the only species that remain in this genus. Phylogenetic and chemotaxonomic evidence indicated that strain $\mathrm{T} 2^{\mathrm{T}}$ should be placed in the genus Micrococcus but that it differed from the other species and represented a new 


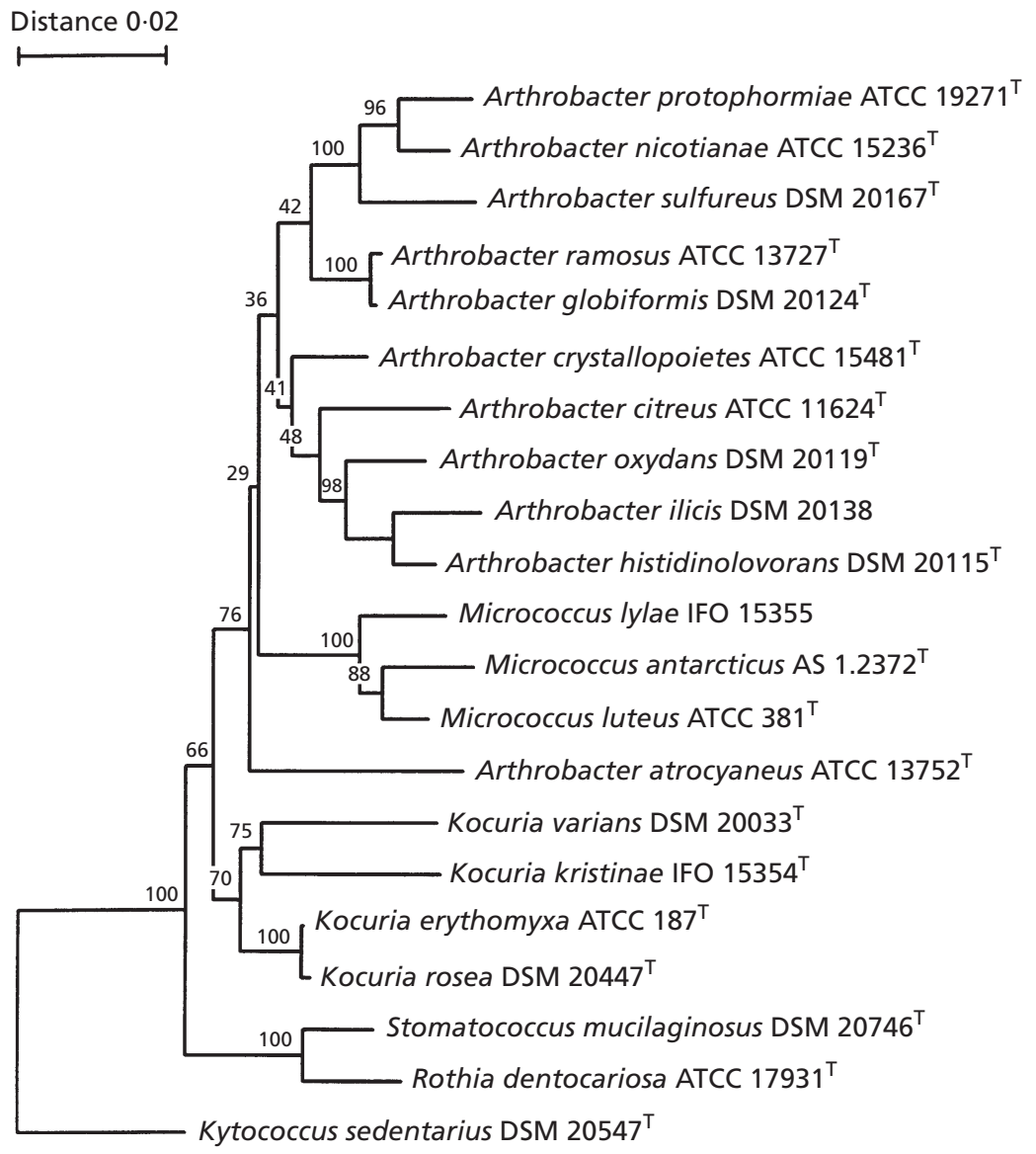

Fig. 2. Phylogenetic tree based on $16 \mathrm{~S}$ rRNA gene sequence divergence, showing the relationships between isolate $\mathrm{T}^{\mathrm{T}}$ and other relatives. The tree was constructed using the neighbour-joining method and the Kimura two-parameter calculation model. The numbers represent the confidence levels from 100-replicate bootstrap sampling. Bar, $0.02 K_{\text {nuc }}$

species within the genus. The low DNA-DNA reassociation value confirmed the new species status of strain $\mathrm{T} 2^{\mathrm{T}}$. Although the above characteristics were consistent with assignment to the genus Micrococcus, the isolate did not conform exactly to any currently validly published species of this genus. On the basis of the phylogenetic findings, in conjunction with the phenotypic distinctiveness of the isolate, we propose the assignment of strain $\mathrm{T}^{\mathrm{T}}$ to a new species, i.e. Micrococcus antarcticus $\mathrm{sp}$. nov.

Our results also indicated members of the genus Micrococcus to be successful in colonizing low-temperature habitats. The psychrophilic isolate $M$. antarcticus AS $1.2372^{\mathrm{T}}$ (strain $\mathrm{T}^{\mathrm{T}}$ ), showed unique characteristics, particularly in its cellular fatty acid profile, which contained a significant amount of an anteiso-branched monounsaturated acid (12-methyl tetradecenoic acid) and was reasonably well adapted to low temperatures. Clearly, the combination of relatively rapid growth at low temperatures and broad metabolic versatility has given this isolate a strong competitive edge in polar environments.

\section{Description of Micrococcus antarcticus sp. nov.}

Micrococcus antarcticus (ant.arc'ti.cus. L. adj. antarcticus opposite the North Star, referring to the Antarctic habitat of the bacterium).
Cells are spherical, have a diameter of $0.5 \mu \mathrm{m}$ and are non-motile. Endospores are not formed. Gram-positive, aerobic. Colonies are yellow, mucoid and fluffy with entire margins. Optimal growth occurs at 15$17^{\circ} \mathrm{C}$. Catalase- and oxidase tests are positive. Positive for the following biochemical tests: indole formation, Voges-Proskauer, methyl red, and nitrate reduction. Starch, Tween 20, Tween 40 and Tween 80 are hydrolysed. The following carbon sources are utilized: arabitol, fructose, fucose, gluconic acid, mannitol, rhamnose, turanose, xylitol, hydroxybutyric acid, Llactic acid, L-malic acid, D-malic acid, methyl pyruvate, mono-methyl succinate, succinamic acid, succinic acid, $\mathrm{N}$-acetyl L-glutamic acid, alaninamide, D-alanine, L-alanine, L-alanyl-glycine, L-asparagine, L-glutamic acid, glycyl-L-glutamic acid, L-pyroglutamic acid, L-serine, glycerol, adenosine, inosine, thymidine and uridine. The following biochemical tests are negative: urease, acetoin, arginine dihydrolase. Gelatin and aesculin are not hydrolysed. Acid production from carbohydrates is negative. The utilization of the following carbon sources is negative: dextrin, glycogen, inulin, mannan, amygdalin, L-arabinose, arbutin, cellobiose, D-galactose, D-galacturonic acid, gentiobiose, D-glucose, myo-inositol, D-lactose, lactulose, maltose, maltotriose, D-mannose, Dmelezitose, D-melibiose, 3-methyl glucose, palatinose, psicose, raffinose, D-ribose, salicin, sorbitol, stachyose, 
sucrose, D-tagatose, D-trehalose, D-xylose, acetic acid, $\alpha$-ketoglutaric acid, $\alpha$-ketovaleric acid, lactamide, propionic acid, pyruvic acid and 2,3-butanediol. Susceptible to lysozyme, penicillin, tetracycline, erythromycin, novobiocin, streptomycin, methicillin, chloramphenicol, polymyxin and neomycin. Cell wall peptidoglycan type is L-lysine (the diagnostic amino acid). The predominant menaquinones are MK-8 and MK-8 $\left(\mathrm{H}_{2}\right)$. The amino sugar in the cell wall polysaccharide is mannosamine. The major cellular fatty acids are anteiso- $\mathrm{C}_{15: 0}(49 \cdot 7 \%)$ and iso- $\mathrm{C}_{15: 0}(19 \cdot 9 \%)$. The $\mathrm{G}+\mathrm{C}$ content of the DNA is $66.4 \mathrm{~mol} \%$ (according to the $T_{\mathrm{m}}$ ). Closely related phylogenetically to Micrococcus luteus and Micrococcus lylae as determined by $16 \mathrm{~S}$ rDNA analysis. The type culture is deposited in the China General Microbiological Culture Collection Centre under the accession number AS $1.2372^{\mathrm{T}}$.

\section{ACKNOWLEDGEMENTS}

This work was partially supported by the grants from State Key Laboratory of Microbial Resources and the National Natural Science Foundation of China.

\section{REFERENCES}

Barrow, G. I. \& Feltham, K. A. (1993). Cowan and Steel's Manual for the Identification of Medical Bacteria, 3rd edn. London: Cambridge University Press.

Bowman, J. P., McCammon, S. A. \& Brown, M. V. (1997). Diversity and association of psychrophilic bacteria in Antarctic sea ice. Appl Environ Microbiol 63, 3068-3078.

Collins, M. D., Bernard, K. A., Hutson, R. A., Sjödén, B., Nyberg, A. \& Falsen, E. (1999). Corynebacterium sundsvallense sp. nov., from human clinical specimens. Int J Syst Bacteriol 49, 361-366.

Felsenstein, J. (1993). PHYLIP-Phylogeny Inference Package (version 3.5). Seattle: Department of Genetics, University of Washington.
Gounot, A. M. (1991). Bacterial life at low temperature: physiological aspects and biotechnological implications. $J$ Appl Bacteriol 71, 386-397.

Kocur, M., Kloos, W. E. \& Schleifer, K. H. (1991). The genus Micrococcus. In The Prokaryotes, pp. 1300-1311. Edited by A. Balows, H. G. Trüper, M. Dworkin, W. Harder \& K. H. Schleifer. New York: Springer.

Nichols, D. S., Nichols, P. D. \& McMeekin, T. A. (1995). Ecology and physiology of psychrophilic bacteria from Antarctic saline lakes and sea-ice. Sci Prog 78, 311-347.

Russell, N. J. (1998). Molecular adaptations in psychrophilic bacteria: potential for biotechnological applications. $A d v$ Biochem Eng Biotechnol 10, 1-21.

Sambrook, J., Fritsch, E. F. \& Maniatis, T. (1989). Molecular Cloning : a Laboratory Manual, 2nd edn. Cold Spring Harbor, NY: Cold Spring Harbor Laboratory.

Schleifer, K. H. \& Kandler, O. (1972). Peptidoglycan types of bacterial cell walls and their taxonomic implications. Bacteriol Rev 36, 407-477.

Sly, L. I., Blackall, L. L., Kraat, P. C., Tian-Shen, T. \& Sangkhobol, V. (1986). The use of second derivative plots for the determination of $\mathrm{mol} \%$ guanine plus cytosine of DNA by the thermal denaturation method. J Microbiol Methods 5, 139-156.

Stackebrandt, E., Koch, C. \& Schumann, P. (1995). Taxonomic dissection of the genus Micrococcus. Int J Syst Bacteriol 45, 682-692.

Thompson, J. D., Higgins, D. G. \& Gibson, T. J. (1994). CLUSTAL $\mathrm{W}$ : improving the sensitivity of progressive multiple sequence alignments through sequence weighting, position-specific gap penalties and weight matrix choice, Nucleic Acids Res 22, 4673-4680.

Tindall, B. J., Ross, H. N. M. \& Grant, W. D. (1984). Natronobacterium gen. nov. and Natronococcus gen. nov., two new genera of haloalkaliphilic archaebacteria. Syst Appl Microbiol 5, 41-57.

Van de Peer, Y. \& De Wachter, R. (1994). TREECON for Windows: a software package for the construction and drawing of evolutionary trees for the Microsoft Windows environment. CABIOS 10, 569-570. 